\title{
The effect of using pretransplant locoregional therapy on the outcome of liver transplantation for HCC patients
}

\author{
Mohamed Rabei Abdelfattah ${ }^{1}$, Mohamed A. Sharaan ${ }^{1}$, Mohamed S. Kamel ${ }^{1}$, Hussein Elsiesy ${ }^{2}$ \\ ${ }^{1}$ Department of Surgery, University of Alexandria, Faculty of Medicine, Alexandria, Arab Republic of Egypt \\ ${ }^{2}$ Organ Transplant Center, King Faisal Specialist Hospital and Research Center, Riyadh, Kingdom of Saudi Arabia
}

Prof. Dr. Mohamed Rabei Abdelfattah. MD, Associate

Professor of Surgery, Department of Surgery, Faculty of Medicine, University of Alexandria, AL Khartoum Square,

Azzaritta, Alexandria, Arab Republic of Egypt, PO BOX

21544

Citation: Abdelfattah MR, Sharaan MA, Kamel MS, Elsiesi H. The effect of using pretransplant locoregional therapy on the outcome of liver transplantation for HCC patients. Cell Ther Transplant 2021; 10(3-4): 46-53.
Phone: 00201023061111 (mob.)

E-mail: Mohamad.rabie@gmail.com

\section{Summary}

Our objective was to assess impact of downstaging locoregional therapy (LRT) on outcome of HCC treated by liver transplantation (LTx), and to assess long-term outcomes of LTx for hepatocellular carcinoma (HCC) and factors affecting them.

\section{Materials and methods}

115 Adult patients underwent LTx as a treatment of HCC between August 2006 and December 2019. As dependent on pre-transplant downstaging LRT, the patients were divided in two groups as follows: group A, patients corresponding to Milan criteria for LTx (MC) who did not receive downstaging LRT prior to LTx; group B included patients beyond Milan criteria who received downstaging LRT pretransplant.

\section{Results}

Among the entire LTx group, the patient, graft, and tumor-free survival rates were $79.7 \%, 90.4 \%$ and $88.2 \%$ respectively. 73 patients had HCC classified within MC (63.5\% of transplanted HCC patients), while the remain-

ing 36.5\% were beyond MC (42 patients). The HCC patients successfully downstaged to the values corresponding to MC criteria showed overall survival and recurrence-free survival comparable to those who were transplanted within MC without LRT. HCC recurrence significantly correlated with detectable vascular invasion and poor degree of tumor differentiation. Moreover, the both features were significantly related to patient survival. Conversely, the transplant criteria and tumor volume $>115 \mathrm{~cm}^{3}$ did not show a significant relation to patient survival or tumor recurrence.

\section{Conclusion}

Our results confirm the importance of biological tumor criteria over the commonly adopted morphological criteria. LRT offers an opportunity to downstage HCC to the values which fit the Milan criteria, while selecting more biologically favorable tumors.

\section{Keywords}

Liver transplantation, hepatocellular carcinoma, locoregional therapy, Milan criteria.

\section{Introduction}

Hepatocellular carcinoma (HCC) is the fifth most common cancer and the most common primary liver malignancy worldwide $[1,2]$. The incidence of HCC has tripled in the United States during the past three decades, with an annual increase of $4.5 \%$ [3]. Additionally, the mortality rates associated with this disease have continued to rise [3, 4]. In Egypt, malignant liver tumors represent $1.7 \%$ of all malignancies and HCC constitutes more than $70 \%$ of these malignancies [5]. Hospital-based studies have reported an overall increase in relative frequency of all liver cancers in Egypt (mainly, HCC), from approximately $4 \%$ in 1993 to $7.3 \%$ in 2003 [6]. 
Currently, since introduction of Milan criteria (MC) of liver transplantation (LTx), this treatment has proven to be an excellent therapeutic option for HCC [7]. Due to the organ shortage, not all transplant-eligible HCC patients undergo LT at the optimal timing. Scarcity of liver grafts and, therefore, longer waiting time result into the disease progression. The predicted probability of dropping from waiting list is estimated as $12 \%$ for the patients with 6 -month delay of tumor treatment $[8,9]$.

In view of sufficient organ shortage, the need for a model to select, prioritize and identify HCC patients with fruitful outcome became crucial. The established transplant criteria, like Milan and UCSF criteria have been well validated and were used as the guideline to select the patients for LTx, especially deceased donor LT [10-12]. Lymphovascular invasion and histological grade of tumor were found to be the most relevant tumor variables to the outcome of HCC patients. Despite that, LT for HCC currently relies on morphological criteria, i.e., number of tumor nodes?, size, and total tumor volume to select HCC patients for LT [6, 13-16].

Unfortunately, most HCC patients are beyond the MC at the time of presentation. Therefore, downstaging to the values fitting for MC is attempted in selected patients. Downstaging is usually performed by a variety of techniques called collectively locoregional therapies (LRT). LRT include radiofrequency ablation (RFA), transarterial chemoembolization (TACE), transarterial radioembolization (TARE), alone or a combination. Downstaging offers many advantages, including decreasing tumor burden and causing less aggressive tumor biology [17]. In 2001, Yao et al. reported the first successful LTx following the HCC downstaging. They showed that successful downstaging of HCC is feasible with a good post LTx outcome [18]. Subsequently, several groups obtained similar outcomes by using different protocols [18-23]. The shortage of the organ grafts requires proper evaluation of the downstaging LRT upon outcomes of HCC treated by LTx, thus determining the aim of our study.

\section{Materials and methods}

A cohort of 115 adult patients underwent LT for the presence of hepatocellular carcinoma (HCC) at our institution between August 2006 and December 2019. Approval from our institutional Research Ethical Committee was obtained before conduction of this study. Cases of pediatric LT or liver retransplantation were excluded from this study.

LTx was performed using both cadaveric and living donor liver transplantation (LDLT). Cases from LDLT were firstand second-degree relatives of their respective patients. HCC was diagnosed by contrast-enhanced computed tomography (CT) and/or abdominal magnetic resonance imaging (MRI). The disease staging was done by chest CT, cranial CT, and technetium-99m bone scintigraphy, to exclude extra-hepatic disease. HCC size, number, tumor grade, and lymph vascular invasion were diagnosed by an experienced pathologist.

For histopathological examination, the 7-point sampling procedure was employed as follows: (1) At least four tissue samples were biopsied from the junction of HCC with nearby hepatic tissue in a $1: 1$ proportion at $12,3,6,9$ o'clock locations, (2) at least one sample should be taken from intra- tumoral region to allow for molecular subtyping, (3) Aiming to exclude the presence of microvascular invasion, satellite, or dysplastic nodules, samples were also obtained from hepatic tissue $\leq 1 \mathrm{~cm}$ and $>1 \mathrm{~cm}$ from HCC margin (adjacent and distant peritumoral locations respectively). (4) The size of tissue blocks was confirmed to be approximately $1.5 \mathrm{~cm}-$ $2.0 \mathrm{~cm} \times 1.0 \mathrm{~cm} \times 0.3 \mathrm{~cm},(5)$ All the specimens were tagged according to the sampling locations.

Liver explant is defined as the native liver of the recipient which was removed in toto by the surgical team as a preparatory step for implanting a new whole liver, or a liver lobe during LTx procedure. Total tumor volume (TTV) was defined as the sum of individual tumor lesion volume; the tumor volume was estimated using the formula $(\mathrm{T}=\{(4 / 3)$ $\left.\pi, r^{3}\right\}$ where $r$ equals the maximum diameter of the lesion measured in $\mathrm{cm}$ ). Presence of mixed HCC and cholangiocarcinoma was a criterion for excluding the case from our study.

Based on the usage of pre-transplant downstaging LRT, patients were divided into the following groups:

- Group A: Patients within Milan criteria (MC) who did not receive pretransplant downstaging LRT.

- Group B: Patients beyond MC who, therefore, received downstaging pretransplant LRT.

Our center currently adopts MC for HCC as the standard criteria for LTx. Any patient who is beyond MC is usually considered for a downstaging protocol by means of one or more locoregional therapies to downstage the tumor to the values fitting within MC. LTx for the downstaged patients is considered after subsequent confirmation of the absence of extrahepatic disease. Pretransplant locoregional therapies included RFA, TACE and TARE.

Evaluation of the response to locoregional therapy was done according to the mRECIST criteria [24]. Accordingly, complete response (CR) was defined as disappearance of any arterial enhancement in all target lesions. Meanwhile, partial response (PR) was defined by at least a 30\% reduction in the sum of diameters of enhancing lesions. Progressive disease (PD) was identified as an increase for, at least, $20 \%$ in the sum of diameters of enhancing lesions. Finally, stable disease (SD) was defined as cases that do not qualify for either (PR) or (PD) [24].

A triple immunosuppression protocol was used for the LT recipients, including calcineurin inhibitor (CNI), corticosteroids and mycophenolate mofetil. Significance of differences and correlations between distinct tumor variables, effects of LRT downstaging, and posttransplant outcomes were assessed by t-test, Chi-square test, one-way ANOVA test, and Pearson's correlation criterion. P-value of $<0.05$ was considered statistically significant. Kaplan-Meier curves were used to express patient survival, graft survival, and tumor-free survival and its significance was determined by log-rank test.

\section{Results}

A cohort of 115 patients underwent LTx between August 2006 and December 2019 at our center. Presence of HCC was the primary indication for LTx. Table 1 is demonstrating pretransplant, transplant, and explant variables for the studied HCC lesions. 
Table 1. Pretransplant, transplant and explant characteristics of the studied HCC patients

\begin{tabular}{|c|c|c|c|c|c|c|}
\hline \multicolumn{4}{|l|}{ Variables } & $\begin{array}{l}\text { Number } \\
\text { (Percentage) }\end{array}$ & Range & $\begin{array}{l}\text { Mean \& standard } \\
\text { deviation }\end{array}$ \\
\hline \multirow{16}{*}{$\begin{array}{l}\text { Pretransplant } \\
\text { variables }\end{array}$} & \multirow{2}{*}{$\begin{array}{l}\text { Patients } \\
\text { Demograp- } \\
\text { hics }\end{array}$} & \multicolumn{2}{|l|}{ Gender } & $\begin{array}{l}\text { Males=79 } \\
\text { Females=36 }\end{array}$ & - & - \\
\hline & & \multicolumn{2}{|l|}{ Age } & - & $39-70$ years & $58.3 \pm 7.1$ years \\
\hline & \multirow{7}{*}{$\begin{array}{l}\text { Indication of } \\
\text { Transplant }\end{array}$} & \multicolumn{2}{|l|}{ HCV } & $69(60 \%)$ & - & - \\
\hline & & \multicolumn{2}{|l|}{ HBV } & $32(27.8 \%)$ & - & - \\
\hline & & \multirow{5}{*}{ 0thers } & Cryptogenic & $6(5.2 \%)$ & - & - \\
\hline & & & NASH & $3(2.6 \%)$ & - & - \\
\hline & & & HCV\&HBV & $2(1.74 \%)$ & - & - \\
\hline & & & Wilson's disease & $2(1.74 \%)$ & - & - \\
\hline & & & Schistosomiasis & $1(0.87 \%)$ & - & - \\
\hline & \multicolumn{3}{|c|}{ Child - Turcot - Pugh (CTP) score } & - & 6-9 points & $7.3 \pm 0.71$ points \\
\hline & \multicolumn{3}{|c|}{$\begin{array}{l}\text { Model for end stage liver disease (MELD) } \\
\text { score }\end{array}$} & - & $11-25$ points & $15.7 \pm 2.5$ points \\
\hline & \multicolumn{3}{|c|}{ alpha feto protein (AFP) } & - & $5-133 \mathrm{ng} / \mathrm{dL}$ & $29.7 \pm 37.1 \mathrm{ng} / \mathrm{dL}$ \\
\hline & \multicolumn{3}{|c|}{ EBV IgM } & 0 & - & \\
\hline & \multicolumn{3}{|l|}{ EBV IgG } & $99(86.1 \%)$ & - & \\
\hline & \multicolumn{3}{|l|}{ CMV IgM } & 0 & - & \\
\hline & \multicolumn{3}{|l|}{ CMV IgC } & 110 (95.7\%) & - & \\
\hline \multirow{6}{*}{$\begin{array}{l}\text { Transplant } \\
\text { \& explant } \\
\text { variables }\end{array}$} & \multicolumn{3}{|c|}{ Type of transplant } & $\begin{array}{l}\text { LDLT }=69(60 \%) \\
\text { DDLT }=46(40 \%)\end{array}$ & - & - \\
\hline & \multicolumn{3}{|l|}{ Tumor size } & - & $0.4-11.5 \mathrm{~cm}$ & $2.78 \pm 1.9 \mathrm{~cm}$ \\
\hline & \multicolumn{3}{|c|}{ Number of lesions } & - & $1-5$ lesions & $1.8 \pm 1.2$ lesion \\
\hline & \multicolumn{3}{|c|}{ Total Tumor Volume (TTV) } & - & $1.2-5594.8 \mathrm{~cm}^{3}$ & $377.8 \pm 812 \mathrm{~cm}^{3}$ \\
\hline & \multicolumn{3}{|c|}{ Tumor Differentiation } & $\begin{array}{l}\text { Well }=24(24 \%)^{\star} \\
\text { Moderate }=70(70 \%)^{\star} \\
\text { Poor }=6(6 \%)^{\star} \\
\text { Unknown }=15(13 \%)\end{array}$ & - & - \\
\hline & \multicolumn{3}{|c|}{ Vascular invasion } & $\begin{array}{l}\text { Present }=9(9 \%)^{*} \\
\text { Unknown = } 15(13 \%)\end{array}$ & - & - \\
\hline
\end{tabular}

Note: ${ }^{*}$, percentage of non necrotic HCC cases

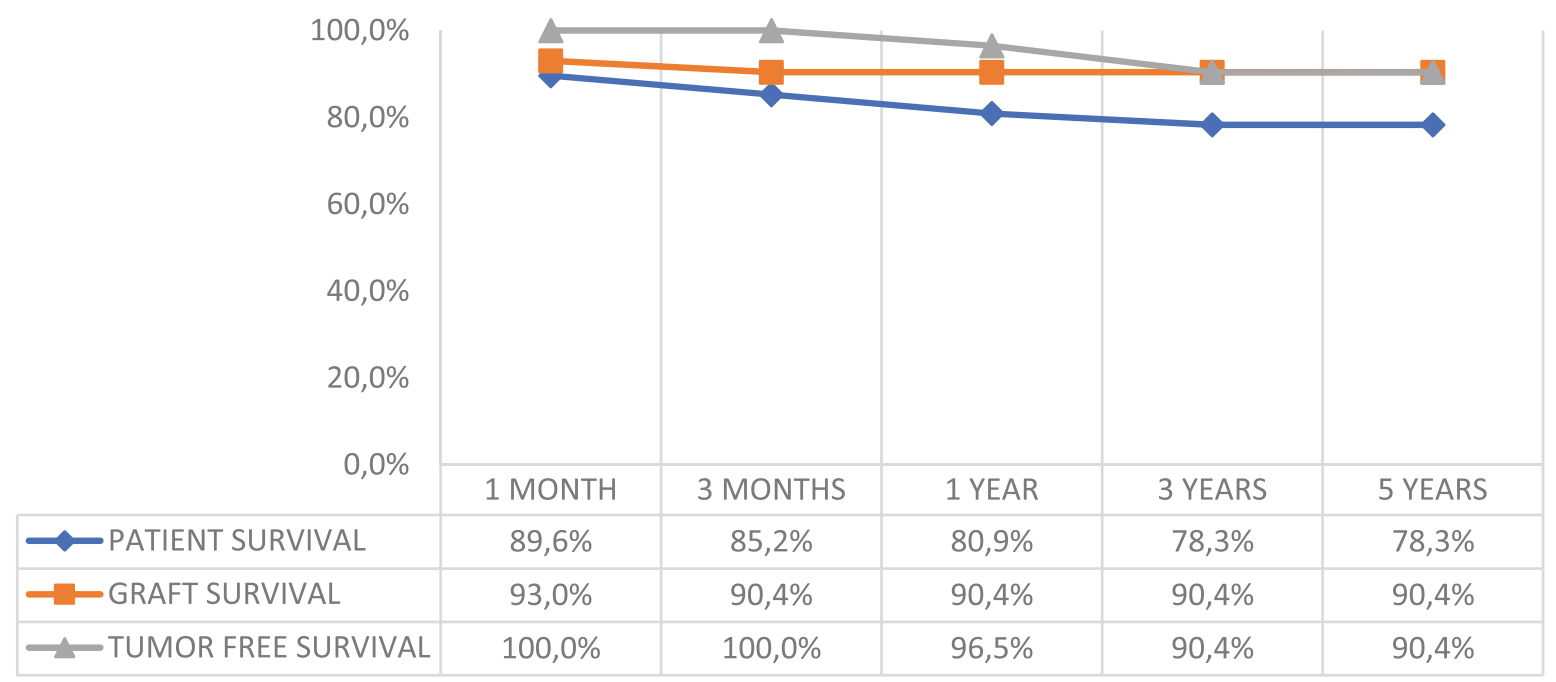

Figure 1. Overall and tumor-free survival, graft survival following LTx for HCC patients 
The degree of tumor differentiation and vascular invasion could not be assessed in 15 cases (13\% of lesions) due to complete necrosis of the lesion caused by LRT prior to LTx. Follow-up period ranged from 24.3-149.9 months, with a mean of $45.98 \pm 33.3$ months. The overall 5-year patient and tumor-free survival, and graft survival rate were $79.7 \%$, $90.4 \%$ and $88.2 \%$, respectively (Fig. 1).

Initially, 136 patients presented with HCC during the study period. Fig. 2 illustrates their distribution, according to their initial HCC burden, LRT and LTx.

Twenty-one patients dropped out while awaiting LT, thus representing $15.4 \%$ dropout for the total HCC group. Therefore, thirteen patients from group A were not transplanted, i.e., 8 patients were delisted due to worsening of their clinical state, and 5 patients, due to progression of HCC beyond the MC $(9.3 \%$ and $5.8 \%$ of HCC patients within MC, respectively).

On the other hand, fifty-five patients were subjected to downstaging LRT, and only 42 of them were eligible for transplant since they showed, at least, partial response. The remaining thirteen patients were excluded from the waiting list, due to stable or progressive disease following the use of LRT. Seventy-three patients had HCC within MC (63.5\% of transplanted HCC patients), while the remaining $36.5 \%$ were beyond MC (42 patients). Only number of HCC nodules and TTV exhibited significant difference between both groups (Table 2).

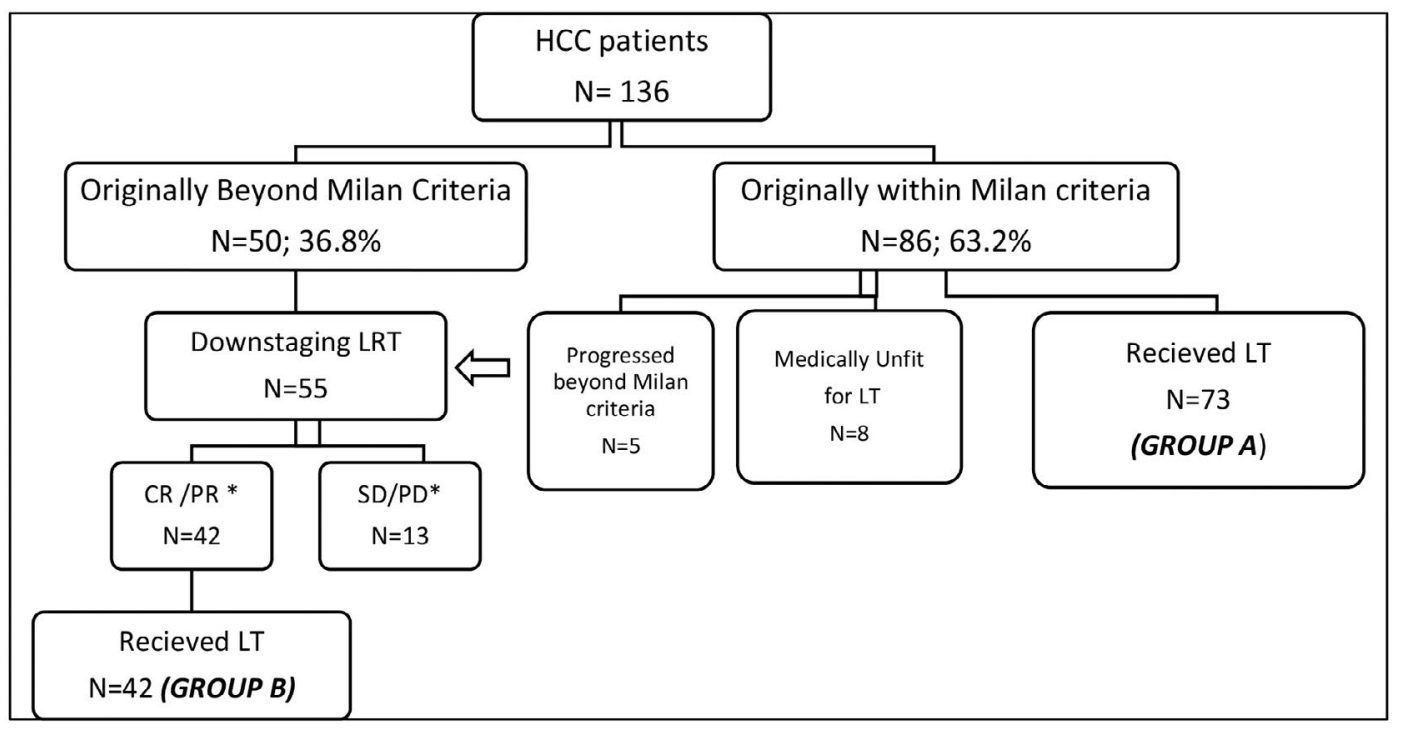

Figure 2. Distribution of HCC patients by their clinical condition during the study period

Note: * Tumor response was assessed according to mRECIST Criteria

Table 2. Comparison of different pretransplant variables between both groups

\begin{tabular}{|l|l|l|l|}
\hline Variables & $\begin{array}{l}\text { Group A } \\
\text { (Within Milan, No LRT) }\end{array}$ & $\begin{array}{l}\text { Group A } \\
\text { (Beyond Milan, received LRT) }\end{array}$ & P value \\
\hline No. of patients & 73 & 42 & - \\
\hline Gender (M/F) & $(50 / 23)$ & $(29 / 13)$ & 0.99 \\
\hline Age (yr) & $58.3 \pm 6.7$ & $58.5 \pm 8.1$ & 0.89 \\
\hline HCV & $45(61.6 \%)^{\star}$ & $24(57.1 \%)^{\star}$ & 0.7 \\
\hline HBV & $18(24.7 \%)^{\star}$ & $14(33.3 \%)^{\star}$ & 0.39 \\
\hline OTHERS & $10(13.9 \%)^{\star}$ & $4(9.5 \%)^{\star}$ & 0.57 \\
\hline CTP Score & $7.4 \pm 0.68$ & $7.25 \pm 0.7$ & 0.29 \\
\hline MELD Score & $15.6 \pm 2.3$ & $16.2 \pm 3$ & 0.25 \\
\hline AFP (ng/dL) & $28.7 \pm 30.9$ & $33.8 \pm 35$ & 0.44 \\
\hline LDLT/DDLT & $(44 / 29)$ & $(25 / 17)$ & 0.99 \\
\hline No. nodules & $1.5 \pm 0.8$ & $2.15 \pm 1.2$ & 0.001 \\
\hline TTV (cm 3 Complete necrosis & $127.2 \pm 144.7$ & $938.3 \pm 1340.9$ & 0.0001 \\
\hline Well & $9(12.3 \%)$ & $6(14.3 \%)$ & 0.78 \\
\hline Moderate & $18(28.1 \%)^{\star \star}$ & $6(16.7 \%)^{\star \star}$ & 0.23 \\
\hline Poor & $44(68.8 \%)^{\star \star}$ & $26(72.2 \%)^{\star \star}$ & 0.82 \\
\hline Micro vascular invasion & $4(6.25 \%)^{\star \star}$ & $2(11.1 \%)^{\star \star}$ & 1 \\
\hline
\end{tabular}

Note: ${ }^{*}$, percentage within the corresponding group; ${ }^{* *}$, after exclusion of 11 cases with total tumor necrosis 
Group A slightly differed from group B as regards the longterm outcomes, but this marginal difference did not reach the level of statistical significance. Patient survival was slightly better in Group A (78.6\% vs $74.4 \%$ at 5 years), with $\mathrm{p}$ value of 0.57 (log-rank test). Similarly, tumor-free survival was slightly better in group A (83.6\% vs $74.2 \%)$ at the 5-year interval $(\mathrm{p}=0.35)$. On the other hand, graft survival was almost the same $90.1 \%$ vs $90.5 \%$ at the 5 years interval in group $A$ and $B$ respectively $(p=0.83)$. Kaplan-Meier graphs for $p a-$ tient, tumor free and graft survival are illustrated in Fig. 3, 4 and 5 , respectively.

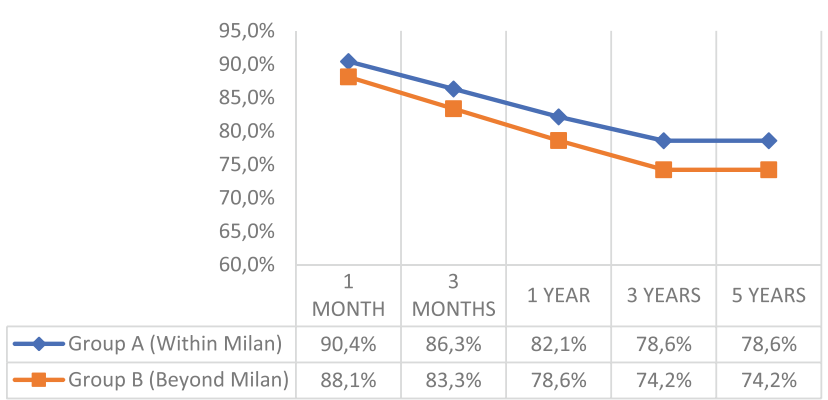

Figure 3. Patient survival curves for group A and B patients following LTx

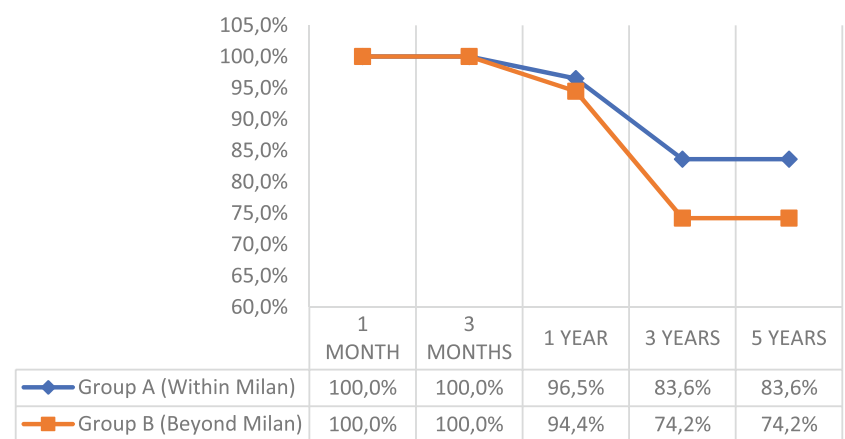

Figure 4. Tumor-free survival curves for group $A$ and B patients following LTx

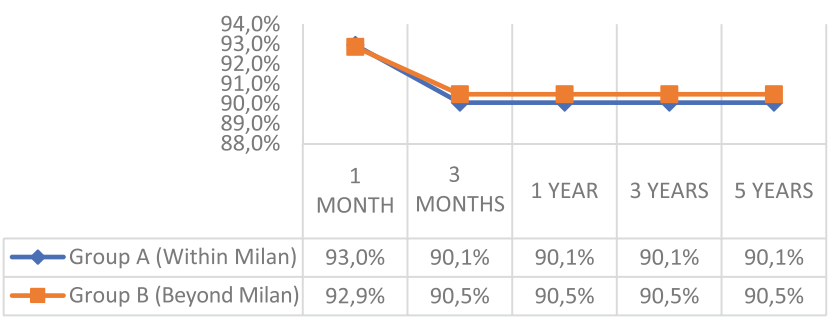

Figure 5. Graft survival curves for group A and B patients following LTx

Twenty-five recipients (21.7\%) died during the follow-up period. 15 were in group A, and 10, in group B. The causes of death among those recipients are listed in Table 3 . The total number of mortalities was statistically insignificant between the groups $\mathrm{A}$ and $\mathrm{B}$ at $\mathrm{p}=0.82$.

HCC recurrence was reported in a total of 11 patients $(9.6 \%$ of transplanted HCC patients). Six cases were reported in group A and five, in group B. Recurrence rates were $8.2 \%$ and $11.9 \%$ in group A and B, respectively $(\mathrm{p}=0.53)$.
Five patients diagnosed with HCC recurrence showed initially lymphovascular invasion in their liver explants, poor tumor differentiation was found in four cases, five patients had moderate tumor differentiation, and 7 patients showed total tumor volume (TTV) of $>115 \mathrm{~cm}^{3}$. HCC recurrence was significantly related to the presence of vascular invasion and poor degree of differentiation. Moreover, both features were significantly related to patient survival. Vice versa, transplant criteria and tumor volume $>115 \mathrm{~cm}^{3}$ showed no significant relation to the patients' survival or tumor recurrence (Table 4).

Seven patients presented solely with distant metastases in lungs $(n=6)$, bones $(n=1)$, and the remaining four patients developed intrahepatic tumor recurrence. Treatment for these cases was scheduled as supportive therapy, along with palliative use of sorafenib if possible.

\section{Discussion}

Currently, LTx offers the best curative chance for patients with HCC on the top of liver cirrhosis, when a liver graft is available [7-9]. Our results correspond with such an opinion, i.e., the overall 5-year patient survival, graft survival, and tumor-free survival were $79.7 \%, 90.4 \%$, and $88.2 \%$, respectively. We observed LTx dropout rate of $15.1 \%$ for the patients

Table 3. Causes and incidence of mortality in liver recipients transplanted for HCC

\begin{tabular}{|l|c|}
\hline Causes of death following LTx & N (\%) \\
\hline HCC recurrence & $11(9.6 \%)$ \\
\hline Small for Size Syndrome (SFSS) & $2(1.74 \%)$ \\
\hline Portal Vein Thrombosis (PVT) & $2(1.74 \%)$ \\
\hline Primary Non-Function (PNF) & $2(1.74 \%)$ \\
\hline Fulminant CMV infection & $2(1.74 \%)$ \\
\hline Disseminated Miliary TB & $2(1.74 \%)$ \\
\hline Sepsis & $1(0.08 \%)$ \\
\hline Pulmonary Embolism & $1(0.08 \%)$ \\
\hline Cerebrovascular Stroke & $1(0.08 \%)$ \\
\hline Chronic rejection & $1(0.08 \%)$ \\
\hline
\end{tabular}

Table 4. Tumor variables affecting HCC recurrence and patient survival

\begin{tabular}{|l|l|l|}
\hline \multirow{2}{*}{ Variables } & \multicolumn{2}{|c|}{ P value } \\
\cline { 2 - 3 } & $\begin{array}{l}\text { HCC } \\
\text { Recurrence }\end{array}$ & Survival \\
\hline Vascular Invasion (N=9) & 0.0003 & 0.003 \\
\hline Poor Differentiation (N=6) & 0.0006 & 0.02 \\
\hline $\begin{array}{l}\text { Total Tumor Volume }>115 \mathrm{~cm}^{3} \\
\text { (N=43) }\end{array}$ & 0.1 & 0.35 \\
\hline $\begin{array}{l}\text { Transplant Criteria } \\
\text { (Within vs beyond Milan } \\
\text { criteria) }\end{array}$ & 0.12 & 0.82 \\
\hline
\end{tabular}


with tumors that corresponded to Milan criteria. The institutional data showed dropout of $11.0 \%$, and $57.4 \%$ at 6 and 12 months for those patients who initially were within MC [8].

Lack of organs for transplants led to development of prioritizing models to use the limited graft pool very efficiently and successfully. In this context, the accumulated evidence of excellent outcomes in the patients transplanted for HCC who fits the Milan criteria lead to adoption of the 22-point bonus system by UNOS [7-9]. There are endless debates on whether a transplant center should embark on adopting MC or more liberal criteria [10-12]. This might indicate that none of the single morphology-based transplant criteria is sufficient when predicting best transplant outcomes in HCC patients, thus raising a need for inclusion of some biological tumor factors into the predictive models $[6,13-16]$.

There have been numerous reports on the tumor downstaging approaches. However, these data are limited by the small number of patients and/or the use of varying downstaging protocols [17-23]. HCC progression in the patients being on waiting list for LTx was found to be an important prognostic factor. It was observed that tumor recurrence after LTx increased from $12 \%$ in the patients remaining within $\mathrm{MC}$ (either spontaneously or following bridging therapy), to $45 \%$ for those with tumor progression beyond the MC [24, 25]. Different criteria were developed to assess the response of HCC to LRT, with mRECIST assessment criteria being the commonly adopted [23, 26-29].

Morphological HCC criteria including TTV $>115 \mathrm{~cm}^{3}$, or being within MC parameters were not shown to significantly influence post-LTx outcome in our HCC patients. Meanwhile, poor tumor differentiation and presence of lymphatic microvascular invasion proved to exert statistically significant influence upon patient survival and HCC recurrence. This finding highlights the importance of biological factors versus morphological variables in determining long-term outcomes following LTx.

Multiplicity of criteria for LTx might partially demonstrate insufficiency of tumor morphologic criteria alone to precise prediction of post-LTx outcomes. The current staging systems for HCC consider only gross tumor morphology. Tumor size and volume appear to reflect the more sufficient biological features of malignancies. Jonas et al. found that tumor diameter and number of HCC lesions in association with pathologic tumor grade predicted the presence of vascular invasion only in HCC lesions $>5 \mathrm{~cm}[13,15]$. Moreover, molecular subtyping appears to be a useful approach to more individualized management of malignant tumors in general, this is also true in the context of HCC. Various studies concentrate now on genetic profiling of HCC lesions. E.g., Marsh et al. investigated DNA mutations in HCC lesions and found the fractional allelic loss (FAI, an index of mutation accumulation), and vascular invasion were the strongest predictors of tumor-free survival $[14,15]$.

Downstaging LRT was used to reverse HCC patients to the clinical stage fitting Milan criteria. This strategy proved to be successful in more than $75 \%$ of cases; $23.6 \%$ were not considered a successful downstaging, due to persistence of stable or progressing disease, according to mRECIST criteria.
The patients successfully downstaged to the condition within MC showed the rates of overall and recurrence-free survival comparable to the patients who corresponded to Milan criteria, being transplanted without initial LRT. In the light of organ shortage, LRT offers an opportunity to downstage HCC to clinical stage within $\mathrm{MC}$, along with selection of more biologically favorable tumors.

Retrospective pattern and relatively small number are among the limitations of our study, thus requiring further studies to confirm such results and to define the role of LRT as a bridge for LTx, aiming for prevention of HCC progression while awaiting LTx.

The era of molecular HCC typing will soon have its influence on HCC management, and introduction of one or more biological markers to the HCC transplant criteria is one of the ways to improve its future therapy.

\section{Conclusion}

The overall results of LTx for HCC at our institution showed an excellent outcome. Presence of lymphatic vascular invasion and poor tumor differentiation are the main factors affecting the long-term post-LTx outcomes. This finding again highlights the importance of biological tumor criteria along with commonly adopted morphological criteria. LRT offers an opportunity to downstage HCC to the clinical state which fits MC, along with choosing more biologically favorable tumors. The successfully downstaged HCC patients who fitted MC, showed overall and recurrence-free survival rates comparable to those who were initially transplanted within MC and without LRT.

\section{Conflict of interest}

Authors have neither conflict of interest, nor financial issues to be disclosed.

\section{References}

1. Llovet JM, Burroughs A, Bruix J. Hepatocellular carcinoma. Lancet. 2003;362(9399):1907-1917. doi: 10.1016/S0140$\underline{6736(03) 14964-1}$

2. Kim DY, Han KH. Epidemiology and surveillance of hepatocellular carcinoma. Liver Cancer. 2012;1(1):2-14. doi: $10.1159 / 000339016$

3. Altekruse SF, McGlynn KA, Reichman ME. Hepatocellular carcinoma incidence, mortality, and survival trends in the United States from 1975 to 2005. J Clin Oncol. 2009;27(9):1485-1491. doi: 10.1200/JCO.2008.20.7753

4. Patel SS, Arrington AK, McKenzie S, Mailey B, Ding M, Lee W, et al. Milan criteria and UCSF criteria: A preliminary comparative study of liver transplantation outcomes in the United States. Int J Hepatol. 2012;2012:253517. doi: $10.1155 / 2012 / 253517$

5. Mokhtar N, Gouda I, Adel I. Malignant digestive system tumors. In: Mokhtar N, Gouda I, Adel I, Eds. Cancer pathology registry, 2003-2004 and time trend analysis. Cairo, Egypt: Elsheraa Press; 2007. pp. 55-67. 
6. el-Zayadi AR, Badran HM, Barakat EM, Attia Mel D, Shawky S, Mohamed MK, et al. Hepatocellular carcinoma in Egypt: a single center study over a decade. World J Gastroenterol. 2005;11(33):5193-5198. doi: 10.3748/wig.v11.i33.5193

7. Mazzaferro V, Regalia E, Doci R, Andreola S, Pulvirenti A, Bozzetti F, et al. Liver transplantation for the treatment of small hepatocellular carcinomas in patients with cirrhosis. N Engl J Med. 1996;334(11):693-699. doi: 10.1056/ $\underline{\text { NEJM199603143341104 }}$

8. Martin AP, Bartels M, Hauss J, Fangmann J. Overview of the MELD score and the UNOS adult liver allocation system. Transplant Proc. 2007;39(10):3169-3174. doi: 10.1016/j. transproceed.2007.04.025

9. United Network for Organ Sharing, "Data reports", https://optn.transplant.hrsa.gov/data/view-data-reports/national-data. Accessed December 17, 2019.

10. Mazzaferro V, Chun YS, Poon RT, Schwartz ME, Yao FY, Marsh JW, et al. Liver transplantation for hepatocellular carcinoma. Ann Surg Oncol. 2008;15(4):1001-1007. doi: 10.1245/s10434-007-9559-5

11. Yao FY, Xiao L, Bass NM, Kerlan R, Ascher NL, Roberts JP. Liver transplantation for hepatocellular carcinoma: validation of the UCSF-expanded criteria based on preoperative imaging. Am J Transplant. 2007;7(11):2587-2596. doi: 10.1111/j.1600-6143.2007.01965.x

12. Mazzaferro V, Llovet JM, Miceli R, Bhoori S, Schiavo M, Mariani L, et al. Predicting survival after liver transplantation in patients with hepatocellular carcinoma beyond the Milan criteria: a retrospective, exploratory analysis. Lancet Oncol. 2009;10(1):35-43. doi: 10.1016/S1470-2045(08)70284-5

13. Jonas S, Bechstein WO, Steinmuller T, Herrmann M, Radke C, Berg T, et al. Vascular invasion and histopathologic grading determine outcome after liver transplantation for hepatocellular carcinoma in cirrhosis. Hepatology. 2001;33(5):1080-1086. doi: 10.1053/jhep.2001.23561

14. Marsh JW, Finkelstein SD, Demetris AJ, Swalsky PA, Sasatomi E, Bandos A, et al. Genotyping of hepatocellular carcinoma in liver transplant recipients adds predictive power for determining recurrence-free survival. Liver Transpl. 2003;9(7):664-671. doi: 10.1053/jlts.2003.50144

15. Abdelfattah MR, Elsiesy H, Al-Manea H, Broering DC. Liver transplantation for hepatocellular carcinoma within the Milan criteria versus the University of California San Francisco criteria: a comparative study. Eur J Gastroenterol Hepatol. 2018;30(4):398-403. doi: 10.1097/MEG.0000000000001044

16. Yao FY, Ferrell L, Bass NM, Bacchetti P, Ascher NL, Roberts JP. Liver transplantation for hepatocellular carcinoma: comparison of the proposed UCSF criteria with the Milan criteria and the Pittsburgh modified TNM criteria. Liver Transpl. 2002;8(9):765-774. doi: 10.1053/jlts.2002.34892

17. Parikh ND, Waljee AK, Singal AG. Downstaging hepatocellular carcinoma: A systematic review and pooled analysis. Liver Transpl. 2015;21(9):1142-1152. doi: 10.1002/lt.24169

18. Yao FY, Ferrell L, Bass NM, Watson JJ, Bacchetti P, Venook A, et al. Liver transplantation for hepatocellular carcinoma: expansion of the tumor size limits does not adverselyimpact survival. Hepatology.2001;33(6):1394-1403. doi: $10.1053 /$ jhep.2001.24563

19. Chapman WC, Majella Doyle MB, Stuart JE, Vachharajani N, Crippin JS, Anderson CD, et al. Outcomes of neoadjuvant transarterial chemoembolization to downstage hepatocellular carcinoma before liver transplantation. Ann Surg. 2008;248(4):617-625. doi: 10.1097/SLA.0b013e31818a07d4

20. Otto G, Herber S, Heise M, Lohse AW, Monch C, Bittinger $\mathrm{F}$, et al. Response to transarterial chemoembolization as a biological selection criterion for liver transplantation in hepatocellular carcinoma. Liver Transpl. 2006;12(8):12601267. doi: $10.1002 /$ lt.20837

21. Ravaioli M, Grazi GL, Piscaglia F, Trevisani F, Cescon M, Ercolani G, et al. Liver transplantation for hepatocellular carcinoma: results of down-staging in patients initially outside the Milan selection criteria. Am J Transplant. 2008;8(12):25472557. doi: 10.1111/j.1600-6143.2008.02409.x

22. Yao FY, Mehta N, Flemming J, Dodge J, Hameed B, Fix $\mathrm{O}$, et al. Downstaging of hepatocellular cancer before liver transplant: long-term outcome compared to tumors within Milan criteria. Hepatology. 2015;61(6):1968-1977. doi: $10.1002 /$ hep. 27752

23. Tohme S, Sukato D, Chen HW, Amesur N, Zajko AB, Humar A, et al. Yttrium-90 radioembolization as a bridge to liver transplantation: a single-institution experience. J Vasc Interv Radiol. 2013;24(11):1632-1638. doi: 10.1016/j. jvir.2013.07.026

24. Lencioni R, Llovet JM. Modified RECIST (mRECIST) assessment for hepatocellular carcinoma. Semin Liver Dis. 2010;30(1):52-60. doi: 10.1055/s-0030-1247132

25. Yao FY, Bass NM, Nikolai B, Merriman R, Davern TJ, Kerlan R, et al. A follow-up analysis of the pattern and predictors of dropout from the waiting list for liver transplantation in patients with hepatocellular carcinoma: implications for the current organ allocation policy. Liver Transpl. 2003;9(7):684-692. doi: 10.1053/jlts.2003.50147

26. Yamashiki N, Gaynor JJ, Kato T, Reddy KR, Sobhonslidsuk A, Levi D, et al. Competing risks analysis of predictors of delisting owing to tumor progression in liver transplant candidates with hepatocellular carcinoma. Am J Transplant. 2004;4(5):774-781. doi: 10.1111/j.1600-6143.2004.00412.x

27. Bruix J, Sherman M, Llovet JM, Beaugrand M, Lencioni R, Burroughs AK, et al. Clinical management of hepatocellular carcinoma. Conclusions of the Barcelona-2000 EASL conference. European Association for the Study of the Liver. J Hepatol. 2001;35(3):421-430. doi: 10.1016/s0168$\underline{\text { 8278(01)00130-1 }}$

28. Bruix J, Sherman M, Practice Guidelines Committee AASLD. Management of hepatocellular carcinoma. Hepatology. 2005;42(5):1208-1236. doi: 10.1002/hep.20933

29. Forner A, Ayuso C, Varela M, Rimola J, Hessheimer AJ, de Lope CR, et al. Evaluation of tumor response after locoregional therapies in hepatocellular carcinoma: are response evaluation criteria in solid tumors reliable? Cancer. 2009;115(3):616-623. doi: $10.1002 /$ cncr.24050 


\title{
Эффект от применения претрансплантационной локорегионарной терапии на исходы трансплантации печени у больных с гепатоцеллюлярной карциномой
}

\author{
Мохамед Рабеи Абдельфаттах ${ }^{1}$, Мохамед А. Шараан ${ }^{1}$, Мохамед С. Камель ${ }^{1}$, Хусейн Эльсиеси ${ }^{2}$ \\ ${ }^{1}$ Департамент хирургии, Университет Александрии, Факультет медицины, Александрия, Египет \\ ${ }^{2}$ Центр трансплантации органов, Специализированный научный госпитальный Центр короля Фейсала, Эр-Рияд, \\ Королевство Саудовская Аравия
}

\section{Резюме}

Наша цель состояла в том, чтобы оценить влияние циторедуктивной локорегиональной терапии (ЛРТ) на исход гепатоцеллюлярной карциномы (ГЦК), леченной посредством трансплантации печени (LTx), а также оценить отдаленные результаты LTx при ГЦК и факторы, влияющие на них.

\section{Материалы и методы}

Наблюдали 115 взрослых пациентов, которым проведена LTx в качестве лечения ГЦК в период с августа 2006 г. по декабрь 2019 г. В зависимости от предтрансплантационной циторедуктивной ЛРТ, пациенты были разделены на две группы следующим образом: группа А - пациенты, соответствующие миланским критериям (MK) для LTx, которые не получали циторедуктивной ЛРТ перед LTx; группа B - пациенты с параметрами опухоли, выходящими за рамки МК, которым была проведена предварительная циторедуктивная ЛРТ.

\section{Результаты}

При анализе по всей выборке общая выживаемость пациентов, трансплантата и безрецидивная выживаемость составили, соответственно, 79,7\%, 90,4\% и $88,2 \%$. Параметры опухоли у 73 пациентов соответствовали миланским критериям (63,5\% пациентов с трансплантированным ГЦК), в то время как у остальных 36,5\% ГЦК превышала критерии МК (42 пациента). У пациентов после успешной циторедукции ГЦК до значений, соответствующих критериям МК, общая и безрецидивная выживаемость были сравнимы с пациентами, которым была проведена трансплантация LRT при соответствии миланским критериям. Рецидив ГЦК достоверно коррелировал с выявленной инвазией в лимфатические сосуды и низкой степенью дифференцировки опухоли. Более того, обе характеристики были существенно связаны с выживаемостью пациентов, и, наоборот, критерии трансплантации и объем опухоли $>115 \mathrm{~cm}^{3}$ не показали значимой связи с выживаемостью пациента или рецидивом опухоли.

\section{Заключение}

Наши результаты подтверждают большую важность биологических критериев опухоли, чем общепринятые морфологические критерии. ЛРТ обеспечивает возможность снизить стадию ГЦК до значений, соответствующих миланским критериям, при одновременном выборе более биологически благоприятных вариантов опухолей.

\section{Ключевые слова}

Трансплантация печени, гепатоцеллюлярная карцинома, локорегионарная терапия, Миланские критерии. 